\title{
Changes in Localization of T Cell Subsets in the Ovarian Follicles during Follicular Growth and Ovulation in Hens
}

\author{
Kalpana Subedi and Yukinori Yoshimura \\ Graduate School of Biosphere Science, Hiroshima University, \\ Higashi-Hiroshima, 739-8528, Japan
}

\begin{abstract}
Changes in the localization of helper and killer $\mathrm{T}$ cells $\left(\mathrm{CD} 4^{+}\right.$and $\mathrm{CD} 8^{+} \mathrm{T}$ cells, respectively) in hen ovarian follicles with follicular growth and ovulation were examined in this experiment. White follicles (WF), the largest and the third largest preovulatory follicles $\left(\mathrm{F}_{1}\right.$ and $\mathrm{F}_{3}$, respectively) and the largest postovulatory follicle (POF) were collected from birds after $5 \mathrm{hrs}$ of oviposition. Cryostat sections were prepared and immunostained for $\mathrm{T}$ cells using antibodies to CD4 (antigen of helper T cells) and CD8 (antigen of cytotoxic $\mathrm{T}$ cells). Populations of positive cells were observed under a light microscope and counted using a computer assisted image analyzer. The $\mathrm{CD}^{+}$and $\mathrm{CD}^{+} \mathrm{T}$ cells were localized in the theca interna and externa of all examined follicles. The frequencies of $\mathrm{CD} 4^{+}$and $\mathrm{CD} 8^{+} \mathrm{T}$ cells in the theca interna were similar among each type of follicles. The frequency of $\mathrm{CD} 4^{+} \mathrm{T}$ cells in the theca externa was significantly decreased in $F_{3}$ and $F_{1}$ compared with WF, with a further decrease in POF $(P<0.05)$, and that of $\mathrm{CD}^{+} \mathrm{T}$ cells was lower in $\mathrm{F}_{3}, \mathrm{~F}_{1}$ and POF than WF $(\mathrm{P}<0.01)$. The ratio of $\mathrm{CD}^{+} / \mathrm{CD}^{+} \mathrm{T}$ cells in the theca interna was similar among each type of follicles but significantly lower in the theca externa of POF than WF, $F_{3}$ and $F_{1}(P<0.05)$. These results suggest that the $\mathrm{T}$ cell subsets, responsible for cell mediated immunity, are reserved in the theca layer of ovarian follicles, whereas their population decreases with follicular growth in theca externa.
\end{abstract}

Key words : follicular growth, laying hens, ovarian follicles, $\mathrm{T}$ cell subsets

\section{Introduction}

Hen ovary consists of cortical follicles embedded in the stroma, numerous white follicles, several yellow preovulatory follicles and postovulatory follicles. White follicles are recruited to enter the rapid growth phase and become yellow follicles. Yellow follicles grow rapidly and enter into hierarchy in size, and larger follicles are supplied by well developed blood vessels. Smaller follicles are the main sites for estrogen production (Bahr and Palmer, 1989 ; Robinson and Etches, 1986), while larger follicles secrete progesterone (Bahr et al., 1983 ; Etches and Duke, 1984). Sex steroids play a role in the local regulation of ovarian function and modulation of immune response, in that

Received : January 11, 2005, Accepted : March 10, 2005

Corresponding author: Y. Yoshimura, Graduate School of Biosphere Sciences, Hiroshima University, Higashi-Hiroshima 739-8528, Japan

Tel/Fax : 082-424-7958 E-mail : yyosimu@hiroshima-u.ac.jp 
estrogen is generally immunoenhancive and progesterone is immunosuppressive in birds (Cheville, 1978). Thus, the population of immune cells may be changed in follicles with the changes in the morphology and functions during the growth of follicles.

$\mathrm{T}$ cells play essential roles in the cell mediated immune response (Schat, 1994 ; Lillehoj and Okamura, 2003 ; Barua and Yoshimura, 2004). Chan et al. (1988) reported that $\mathrm{T}$ cell subsets are helper/inducer $\mathrm{T}$ cells with CD4 antigen (CD4 ${ }^{+} \mathrm{T}$ cells) and cytotoxic/suppressor $\mathrm{T}$ cells with $\mathrm{CD} 8$ antigen $\left(\mathrm{CD} 8^{+} \mathrm{T}\right.$ cells $) . \mathrm{CD}^{+} \mathrm{T}$ cells respond to antigens presented by $\mathrm{MHC}$ class II of antigen presenting cells and $\mathrm{CD} 8^{+} \mathrm{T}$ cells do to the antigens presented by MHC class I of intracellularly infected cells (Swain, 1983). CD4 ${ }^{+} \mathrm{T}$ cells stimulate antibody production of $\mathrm{B}$ cells and phagocytosis of macrophages (Davison, 1996 ; Gobel, 1996), whereas CD8 ${ }^{+}$T cells kill infected cells and suppress lymphocyte activities (Chen et al., 1994).

$\mathrm{T}$ cell subsets have been localized in the ovarian stroma and theca of primary follicles (Barua and Yoshimura, 1999), and in atretic follicles (Yoshimura and Kitamura, 2002) of laying hens. They may play significant roles not only in protection of ovarian tissue from the infection (Barua and Yoshimura, 2004) but also in the regulation of ovarian function such as promotion of regression of atretic follicles (Yoshimura and Kitamura, 2002). A decline of $\mathrm{T}$ cells population was reported in ovarian stroma and theca layer of primary follicles in response to aging (Barua and Yoshimura, 1999). The $\mathrm{T}$ cell subsets were increased by stimulation with estrogen in the ovary of immature hens (Barua and Yoshimura, 1999). However, the changes in the $\mathrm{T}$ cells population in growing and postovulatory follicles of healthy birds, which may occur in association with changes in morphology and functions of follicles, have not been studied. Thus, the aim of this study was to determine the localization of CD4 ${ }^{+}$ and $\mathrm{CD} 8^{+} \mathrm{T}$ cells and also the changes in their frequencies with follicular growth and postovulation in the follicles of laying hens.

\section{Materials and Methods}

\section{Birds}

White Leghorn hens regularly laying 5 or more eggs in a sequence were used (approximately 200-d-old ; $n=5$ ). They were kept in individual cages under a light regimen of $14 \mathrm{hrs}$ light : $10 \mathrm{hrs}$ dark, and provided with feed and water at ad libitum. Tissue Collection and Immunocytochemistry

Birds were euthanized by decapitation after $5 \mathrm{hrs}$ of oviposition, namely approximately $20 \mathrm{hrs}$ before expected time of ovulation. Handling of birds was done in accordance with Hiroshima University regulations for the conduct of animal experiments. Cryostat sections ( $15 \mu \mathrm{m}$ thickness) were prepared from white follicles (WF ; approximately $3-5 \mathrm{~mm}$ in diameter), the third largest and the largest preovulatory follicles $\left(F_{3}\right.$ and $F_{1}$, respectively) and the largest postovulatory follicle (POF ; $5 \mathrm{hrs}$ after oviposition). Sections were air-dried on aminpropyltriethoxy-silane treated slides and fixed with acetone for $15 \mathrm{~min}$. Then the sections were immunostained for CD4 and CD8 as described by Barua et al. (2001). Briefly, sections were incubated with mouse anti-chicken CD4 or mouse anti-chicken CD8 antibodies (Southern Biotechnology 
Associates, Inc., USA) at a dilution of $1: 200$ in phosphate buffered saline containing $1 \%(\mathrm{w} / \mathrm{v})$ bovine serum albumin (PBS-BSA) for overnight, followed by washing with phosphate buffer saline (PBS) for $15 \mathrm{~min}$ ( $5 \mathrm{~min} \times 3$ times $)$.

Immunoreactions of the first antibodies were detected by Histofine SAB-Po (M) kit (Nichirei Co., Tokyo, Japan). Briefly, sections were incubated with biotinylated anti-mouse $\operatorname{IgG}+\operatorname{IgM}+\operatorname{IgA}$, and avidin peroxidase complex for $1 \mathrm{hr}$ each, followed by washing with PBS ( $5 \mathrm{~min} \times 3$ times) in each step. Immunoprecipitates were visualized by incubation with $0.02 \%(\mathrm{w} / \mathrm{v}) 3^{\prime}, 3^{\prime}$-diaminobenzidine tetrahydrochloride and $0.001 \%$ (w/v) $\mathrm{H}_{2} \mathrm{O}_{2}$ in $0.05 \mathrm{M}$ Tris- $\mathrm{HCl}$ buffer ( $\mathrm{pH}$ 7.6). Then sections were counterstained with hematoxylin, dehydrated and covered. Control staining was carried out simultaneously in which first antibody was replaced with normal mouse IgG (Funakoshi Inc. Tokyo, Japan) diluted $1: 25$ in PBS. No specific staining was found in control slides.

Then the sections were examined under a light microscope with image analysis software (Image-Pro Plus, Media Cybernetics, Silver Spring, MD). The numbers of immunopositive cells were obtained by observing three different regions of theca interna (approximately $1.0-2.0 \times 10^{5} \mu \mathrm{m}^{2}$ tissue) and theca externa (approximately $2.5-4.5 \times$ $10^{5} \mu \mathrm{m}^{2}$ tissue) in one section. More than three sections were examined in one follicle. The mean of the counts was calculated to be the number of cells in $1 \times 10^{4} \mu \mathrm{m}^{2}$ tissue of theca interna or externa of a follicle.

Statistical Analysis

The significance of differences in the number of positive cells among each follicular type was determined by one way ANOVA followed by Duncan's multiple range test and that between theca interna and externa was examined by Student's t-test. Differences were considered significant when $\mathrm{P}<0.05$.

\section{Results}

The wall of WF, $F_{3}, F_{1}$ and POF consisted of granulosa, theca interna, theca externa and superficial layers. Theca interna consisted of cell-rich connective tissue and contained capillaries. The theca externa consisted of dense connective tissue and the density of the connective tissue was higher in $F_{3}$ and $F_{1}$ compared with WF. The wall of POF showed a contracted appearance with thick theca and folded granulosa layer. The $\mathrm{CD}^{+}$and $\mathrm{CD} 8^{+} \mathrm{T}$ cells were localized in the theca interna and externa but not in granulosa layer of WF, $F_{3}, F_{1}$ and POF (Figs. 1 and 2).

The frequency of $\mathrm{CD}^{+}{ }^{+} \mathrm{T}$ cells in the theca layer of $\mathrm{WF}, \mathrm{F}_{3}, \mathrm{~F}_{1}$ and POF is shown in Fig. 3. The frequency in the theca interna was not different among WF, $F_{3}, F_{1}$ and POF. In contrast, the CD4 ${ }^{+} \mathrm{T}$ cells in the theca externa were significantly decreased in $\mathrm{F}_{3}$ and $\mathrm{F}_{1}$ compared with WF $(\mathrm{P}<0.05)$ and further decreased in POF $(\mathrm{P}<0.01)$. The frequency of $\mathrm{CD}^{+} \mathrm{T}$ cells was significantly lower in theca externa than in theca interna in $\mathrm{F}_{3}, \mathrm{~F}_{1}$ and POF $(\mathrm{P}<0.01)$. There was no difference in the frequency of $\mathrm{CD}^{+} \mathrm{T}$ cells in the theca interna among $\mathrm{WF}, \mathrm{F}_{3}, \mathrm{~F}_{1}$ and POF, and that in the theca externa was significantly greater in WF than in $F_{3}, F_{1}$ and POF $(P<0.01)$ (Fig. 4). The frequency of $\mathrm{CD}^{+} \mathrm{T}$ cells was also significantly lower in the theca externa than in the thea 

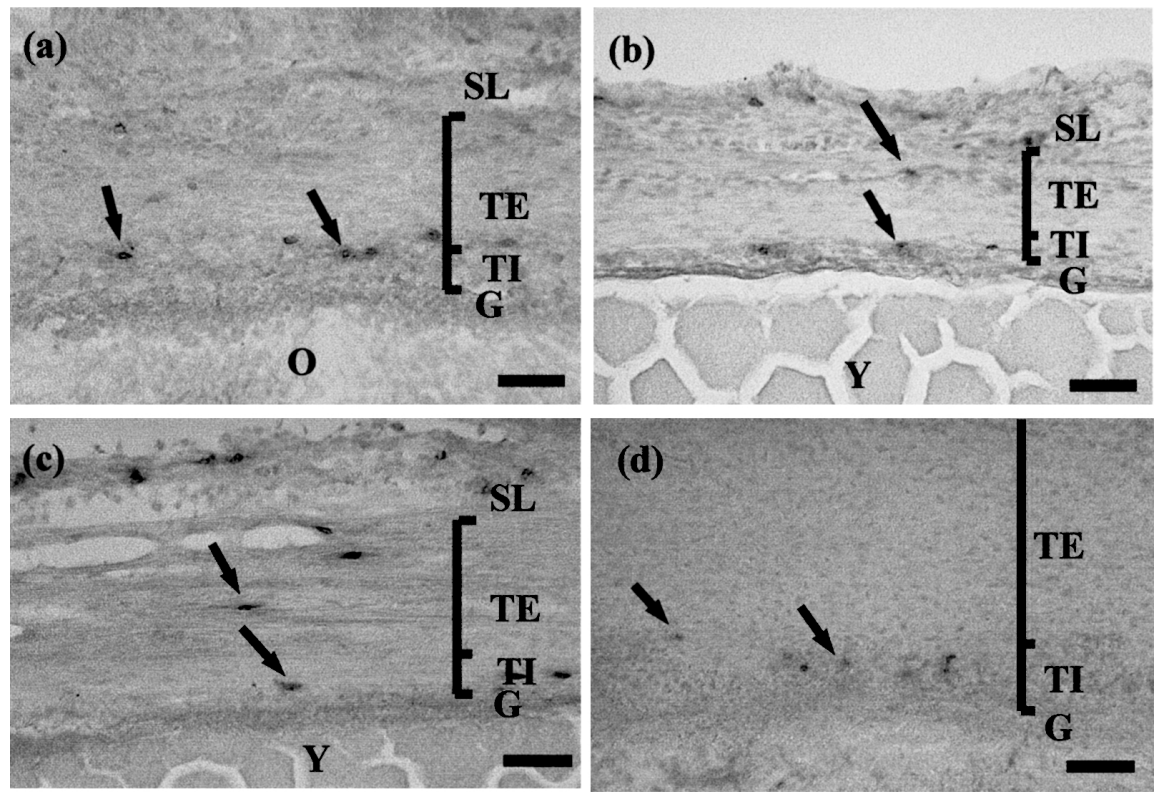

Fig. 1. Sections of ovarian follicles immunostained for CD4 T cells.

(a), (b), (c) and (d) show the sections of white follicle, the third largest follicle, the largest follicle and the largest postovulatory follicle, respectively. Arrows indicate the examples of CD4 positive cells in the theca interna and externa. G: granulosa layer; O : oocyte, SL : superficial layer; TI : theca interna, TE : theca externa, Y : yolk.

Scale bars represent $40 \mu \mathrm{m}$.

interna in $\mathrm{F}_{3}, \mathrm{~F}_{1}$ and $\mathrm{POF}(\mathrm{P}<0.05)$.

The ratio of $\mathrm{CD}^{+} / \mathrm{CD}^{+} \mathrm{T}$ cells in the theca interna was not different among WF, $F_{3}, F_{1}$ and POF (Fig. 5). The ratio in the theca externa of POF was significantly lower as compared to that of WF, $F_{3}$ and $F_{1}(P<0.05)$ and also lower than that in theca interna of POF $(\mathrm{P}<0.01)$.

\section{Discussion}

We are reporting that the localization of $\mathrm{T}$ cell subsets in ovarian follicles changes with follicular growth and postovulatory regression. The significant findings of this study were : (i) $\mathrm{CD}^{+}$and $\mathrm{CD} 8^{+} \mathrm{T}$ cells were localized in both theca interna and externa but not in granulosa layer of follicles, (ii) the frequencies of $\mathrm{CD} 4^{+}$and $\mathrm{CD} 8^{+}$ $\mathrm{T}$ cells in the theca interna did not change with follicular growth, whereas they were significantly declined in the theca externa with follicular growth from WF to $F_{3}, F_{1}$ and $\mathrm{POF}$, and (iii) the ratio of $\mathrm{CD} 4^{+} / \mathrm{CD} 8^{+} \mathrm{T}$ cells was not different in the theca interna among each type of follicles, but the ratio decreased in the theca externa of POF compared with WF, $\mathrm{F}_{3}$ and $\mathrm{F}_{1}$.

$\mathrm{T}$ cell subsets were located in the theca interna and externa but not in granulosa layer. Previous reports also suggested that $\mathrm{T}$ cells were present in the theca layers but not in granulosa layer of prehierarchal follicles of healthy hens (Barua and Yoshimura, 

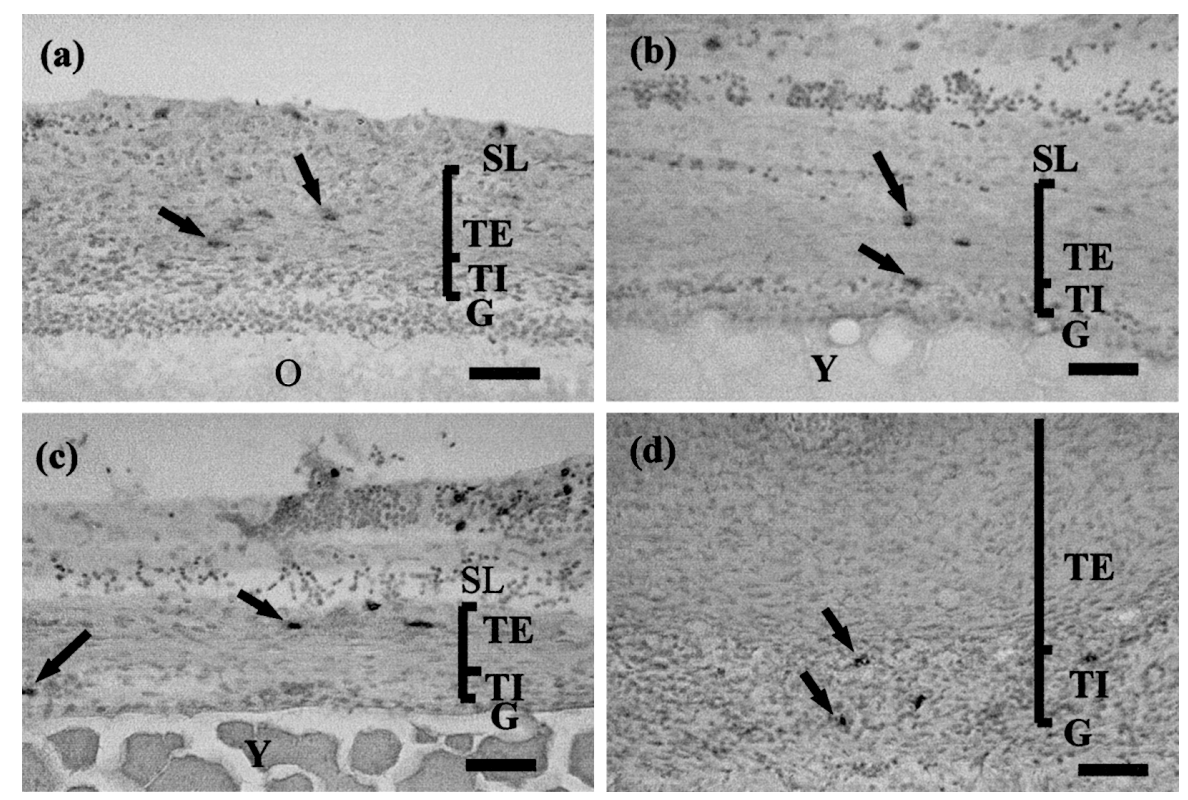

Fig. 2. Sections of ovarian follicles immunostained for CD8 T cells.

(a), (b), (c) and (d) show the sections of white follicle, the third largest follicle, the largest follicle and the largest postovulatory follicle, respectively.

See Fig. 1 for other explanations.

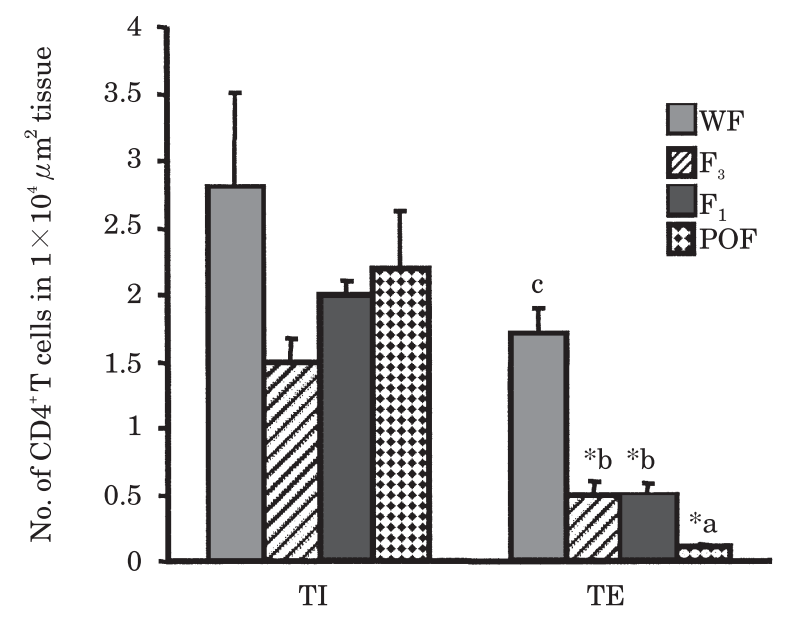

Fig. 3. Changes in the frequency of CD4 $\mathrm{T}$ cells in the theca interna and externa with follicular growth and ovulation.

$\mathrm{WF}$ : white follicle, $\mathrm{F}_{3}$ : the third largest follicle, $\mathrm{F}_{1}$ : the largest follicle, POF : postovulatory follicle, TI: theca interna, TE: theca externa. Each value shows mean $\pm \mathrm{SEM}$ of the number of CD4 $\mathrm{T}$ cells in $1 \times 10^{4} \mu \mathrm{m}^{2}$ area $(\mathrm{n}=5)$. Bars with different letters are significantly different within theca externa ( $P$ $<0.05)$. * Significantly different between theca interna and externa within corresponding follicular type $(\mathrm{P}<0.01)$. 


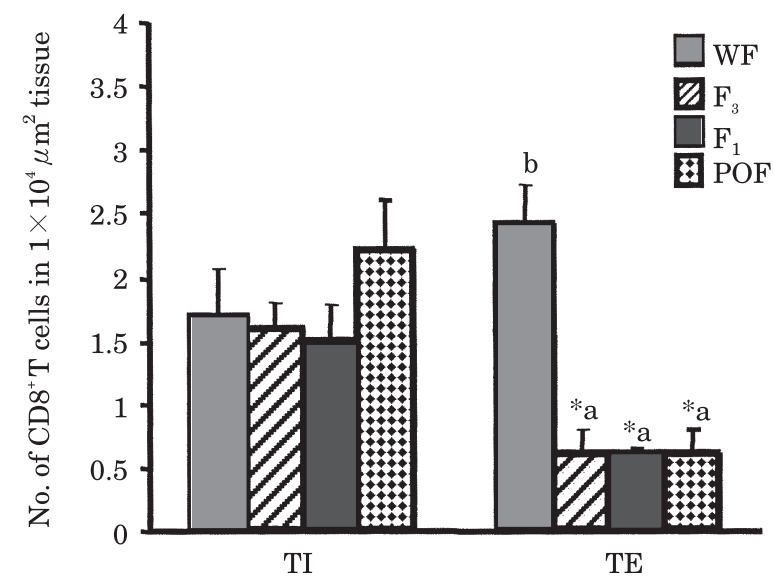

Fig. 4. Changes in the frequency of CD8 $\mathrm{T}$ cells in the theca interna and externa with follicular growth and ovulation.

Each value shows mean \pm SEM of the number of CD8 T cells in $1 \times 10^{4} \mu \mathrm{m}^{2}$ area $(n=5)$. Bars with different letters are significantly different within theca externa $(\mathrm{P}<0.05)$. * Significantly different between theca interna and externa within corresponding follicular type $(\mathrm{P}<0.05)$.

See Fig. 3 for explanations of abbreviations.

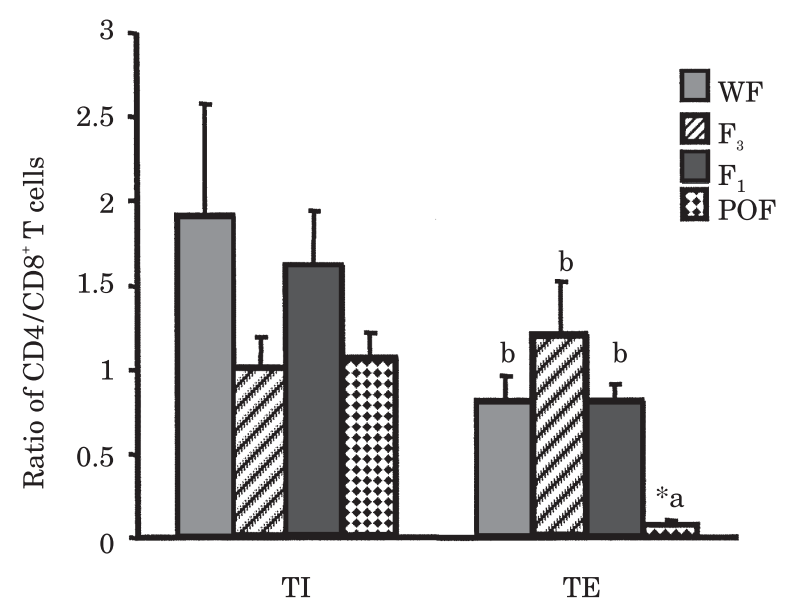

Fig. 5. Changes in the ratio of $\mathrm{CD} 4 / \mathrm{CD} 8 \mathrm{~T}$ cells in theca interna and externa with follicular growth and ovulation.

Each value shows mean \pm SEM of the ratio of CD4/CD8 $T$ cells $(n=5)$. Bars with different letters are significantly different within theca externa $(\mathrm{P}<$ 0.05). * Significantly different between theca interna and externa within corresponding follicular type $(\mathrm{P}<0.01)$.

See Fig. 3 for explanations of abbreviations.

1999 ; Yoshimura and Kitamura, 2002 ; Barua and Yoshimura, 2004). These findings indicate that $\mathrm{T}$ cells are reserved in the theca layers, suggesting that this tissue is the primary site where cell mediated immune response occurs in follicles. The expressions 
of MHC class I and II, which are responsible in the antigen presentation to $\mathrm{CD} 8^{+}$and $\mathrm{CD}^{+} \mathrm{T}$ cells, respectively, have been shown in the thecal tissues (Subedi and Yoshimura, 2005). The basal lamina is structurally the barrier between the theca and granulosa layers, which may prevent the infiltration of $\mathrm{T}$ cells into the granulosa layer and oocyte of healthy follicles. Autoimmunity to ovarian antigens may occur to reduce egg production in hens, and $\mathrm{T}$ cells are one of the key members to cause autoimmunity (Barua and Yoshimura, 2001). In mammals, it is reported that ovarian autoimmunity may occur as a result of recognition of oocyte and zona pellucida as antigen by immune cells (Monacayo and Monacayo, 1992). Thus the prohibition of T cells infiltration into granulosa layer and oocyte is important to prevent the induction of autoimmunity.

The theca interna contained stable population of $\mathrm{CD}^{+}$and $\mathrm{CD} 8^{+} \mathrm{T}$ cells in $\mathrm{WF}$, $F_{3}, F_{1}$ and POF, whereas their population in the theca externa was significantly decreased in $\mathrm{F}_{3}, \mathrm{~F}_{1}$ and POF compared with WF. The structure of the theca interna does not change with follicular growth, namely it consists of cell-rich connective tissue and is provided with capillaries in each type of follicles. Such structural characteristics of theca interna may be responsible for the constant $\mathrm{T}$ cells influx into this tissue during follicular growth. In contrast, the density of the connective tissue of theca externa increased with follicular growth. Thus the increase of tissue density may be one of the factors responsible for the less influx of both $\mathrm{CD} 4^{+}$and $\mathrm{CD} 8{ }^{+} \mathrm{T}$ cells in larger follicles and POF. Also the difference of the tissue density between the theca interna and externa may cause a greater population of $\mathrm{T}$ cells in theca interna than in the thea externa of $\mathrm{F}_{3}, \mathrm{~F}_{1}$ and POF.

Ovulation resembles an inflammatory reaction where leucocytes, fibroblasts macrophages readily infiltrate the site of inflammation especially during the repair phase of the process in mammals (Espey, 1980). However, T cells may not be required in ovulation and early phase of postovulatory regression of follicles because significant increase in their population was not obtained in POF. The ratio of $\mathrm{CD} 4^{+} / \mathrm{CD} 8^{+} \mathrm{T}$ cells was not changed among WF, $\mathrm{F}_{3}$ and $\mathrm{F}_{1}$ in both theca interna and externa. The decrease in the ratio of $\mathrm{CD}^{+} / \mathrm{CD} 8^{+} \mathrm{T}$ cells occurred only in the theca externa of POF which was due to the more decrease in the number of $\mathrm{CD}^{+} \mathrm{T}$ cells than $\mathrm{CD} 8^{+} \mathrm{T}$ cells. Therefore, it is likely that a balanced population of $\mathrm{T}$ cells is kept in healthy growing follicles, and such a balanced $\mathrm{T}$ cells population has been suggested necessary for normal functioning of follicles (Michael, 1983). The decline of ratio in the POF suggests that $\mathrm{CD}^{+} \mathrm{T}$ cell mediated immunity may decline more rapidly than $\mathrm{CD} 8^{+} \mathrm{T}$ cell mediated one in postovulatory follicles.

Collectively, the results of this study indicate that $\mathrm{T}$ cell subsets are reserved in the theca layers, and the population of both $\mathrm{CD} 4^{+}$and $\mathrm{CD} 8^{+} \mathrm{T}$ cells in follicles declines with follicular growth, specifically in theca externa. The greater population of both types of $T$ cells in the theca interna than theca externa suggests that theca interna is the primary site for cell mediated immunity.

\section{Acknowledgement}

This work was supported by Grant-in-Aid for Scientific Research from the Minis- 
try of Education, Culture, Sports, Science and Technology, Japan.

\section{References}

Bahr JM and Palmer S S. The influence of aging on ovarian function. Critical Reviews in Poultry Biology, 2 : 103-110. 1989.

Bahr JM, Wang SC, Huang MY and Calvo FO. Steroid concentration in isolated theca and granulosa layers of preovulatory follicles during the ovulatory cycle of the domestic hen. Biology of Reproduction, 29 : 326-334. 1983.

Barua A and Yoshimura Y. Effects of aging and sex steroids on the localization of T cell subsets in the ovary of chicken, Gallus domesticus. General and Comparative Endocrinology, 114 : 28-35. 1999.

Barua A and Yoshimura Y. Ovarian autoimmunity in relation to egg production in laying hens. Reproduction, $121: 117-122.2001$.

Barua A and Yoshimura Y. Ovarian cell-mediated immune response to Salmonella enteritidis infection in laying hens (Gallus domesticus). Poultry Science, 83 : 997-1002. 2004.

Barua A, Michiue H and Yoshimura Y. Changes in the localization of MHC class II positive cells in hen ovarian follicles during the processes of follicular growth, postovulatory regression and atresia. Reproduction, $121: 953-957.2001$.

Chan MM, Chen CH, Ager LL and Cooper MD. Identification of the avian homologues of mammalian CD4 and CD8 antigens. Journal of Immunology, $140: 2133-2138.1988$.

Chen CH, Gobel TWF, Kubota T and Cooper MD. T cell development in the chicken. Poultry Science, 73 : 1012-1018. 1994.

Cheville NF. Environmental factors affecting the immune response in birds. Avian Diseases, 23 : 308-314. 1978.

Davison TF. Cell-mediated immunity : effector functions. In : Poultry Immunology (Davison TF, Morris TR and Payne LN eds.). pp. 115-134. Carfax Publishing Company, England. 1996.

Espey LL. Ovulation as an inflammatory reaction- A hypothesis. Biology of Reproduction, 22 : 73-106. 1980.

Etches RJ and Duke CE. Progesterone, androstenedione and oestradiol content of the theca and granulosa tissues of the four largest ovarian follicles during the ovulatory cycle of the hen (Gallus domesticus). Journal of Endocrinology, 103 : 71-76. 1984.

Gobel TWF. The T-dependent immune system. In : Poultry Immunology (Davison TF, Morris TR and Payne LN eds.). pp. 31-45. Carfax Publishing Company, England. 1996.

Lillehoj $\mathrm{H}$ and Okamura M. Host immunity and vaccine development to coccidia and Salmonella infections in chickens. Journal of Poultry Science, $40: 151-193.2003$.

Michael SD. Interaction of the thymus and the ovary. In : Factors regulating ovarian function (Greenwald GS and Terranova PF eds.). pp. 445-464. Raven Press, New York. 1983.

Monacayo R and Monacayo HE. Autoimmunity and the ovary. Immunology Today, 13 : 255258. 1992.

Robinson FE and Etches RJ. Ovarian steroidogenesis during follicular maturation in the domestic fowl (Gallus domesticus). Biology of Reproduction, 35 : 1096-1105. 1986.

Schat K. Cell-mediated immune effector function in chickens. Poultry Science, $73: 1077-1081$. 1994.

Subedi K and Yoshimura Y. Expression of MHC class I and II in growing ovarian follicles of young and old laying hens, Gallus domesticus. Journal of Poultry Science, 42 : 101-109. 2005.

Swain SL. T cell subsets and the recognition of MHC class. Immunological Reviews, 74 : 129142. 1983.

Yoshimura Y and Kitamura A. Changes in the population of lymphocytes expressing CD4 and CD8 during the process of atresia of white follicles in hens. Animal Science Journal, 73 : 457-463. 2002. 